\title{
Surgical-orthodontic treatment of Class III malocclusion with agenesis of lateral incisor and unerupted canine
}

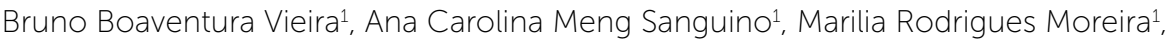 \\ Elizabeth Norie Morizono², Mírian Aiko Nakane Matsumoto ${ }^{3}$
}

Introduction: Orthodontic-surgical treatment was performed in patient with skeletal Class III malocclusion due to exceeding mandibular growth. Patient also presented upper and lower dental protrusion, overjet of $-3.0 \mathrm{~mm}$, overbite of $-1.0 \mathrm{~mm}$, congenital absence of tooth \#22, teeth \#13 and supernumerary impaction, tooth \#12 with conoid shape and partly erupted in supraversion, prolonged retention of tooth \#53, tendency to vertical growth of the face and facial asymmetry. The discrepancy on the upper arch was $-2.0 \mathrm{~mm}$ and $-5.0 \mathrm{~mm}$ on the lower arch. Methods: The pre-surgical orthodontic treatment was performed with extractions of the teeth \#35 and \#45. On the upper arch, teeth \#53, \#12 and supernumerary were extracted to accomplish the traction of the impacted canine. The spaces of the lower extractions were closed with mesialization of posterior segment. After aligning and leveling the teeth, extractions spaces closure and correct positioning of teeth on the bone bases, the correct intercuspation of the dental arch, with molars and canines in Angle's Class I, coincident midline, normal overjet and overbite and ideal torques, were evaluated through study models. The patient was submitted to orthognathic surgery and then the post-surgical orthodontic treatment was finished. Results: The Class III malocclusion was treated establishing occlusal and facial normal standards.

Keywords: Orthodontics. Angle Class III malocclusion. Oral surgery.

Introdução: o presente trabalho apresenta um tratamento ortodôntico-cirúrgico realizado em paciente portadora de má oclusão de Classe III esquelética com crescimento mandibular, protrusão dentária superior e inferior, trespasse horizontal de $-3,0 \mathrm{~mm}$, trespasse vertical de $-1,0 \mathrm{~mm}$, ausência congênita do dente 22, dentes 13 e supranumerários inclusos, dente 12 com forma conoide e parcialmente irrompido em supraversão, retenção prolongada do dente 53 , tendência ao crescimento vertical da face e assimetria facial. A discrepância na arcada superior era de $-2,0 \mathrm{~mm}$, e na inferior era de $-5,0 \mathrm{~mm}$. Métodos: o tratamento ortodôntico pré-cirúrgico foi realizado com extrações dos dentes 35 e 45 . Na arcada superior foram extraídos os dentes 53,12 e supranumerário, para efetuar o tracionamento do canino incluso. Os espaços das extrações inferiores foram fechados com mesialização do segmento posterior. Após o alinhamento e nivelamento dos dentes, foram avaliados por meio de modelos de estudo o fechamento dos espaços das extrações e o posicionamento correto dos dentes nas bases ósseas, a intercuspidação correta das arcadas dentárias, com molares e caninos em Classe I de Angle, linhas medianas coincidentes, trespasse horizontal e trespasse vertical normais e torques ideais. A paciente foi encaminhada para realização de cirurgia ortognática e, em seguida, o tratamento ortodôntico pós-cirúrgico foi finalizado. Resultados: a má oclusão de Classe III foi corrigida, estabelecendo padrões oclusais e faciais normais.

Palavras-chave: Ortodontia. Má oclusão de Classe III de Angle. Cirurgia bucal.

» The patient displayed in this article previously approved the use of her facial and intraoral photographs.

${ }^{1}$ Post-Graduation Student, FORP-USP.

${ }^{2}$ Professor at the Specialization Course in Orthodontics, FORP-USP.

${ }^{3}$ Associated Professor at the Department of Pediatric Clinic, Preventive and Social Dentistry, FORP-USP.
How to cite this article: Vieira BB, Sanguino ACM, Moreira MR, Morizono EN, Matsumoto MAN. Surgical-orthodontic treatment of Class III malocclusion with agenesis of lateral incisor and unerupted canine. Dental Press J Orthod. 2013 May-June;18(3):94-100.

Submitted: January 29, 2010 - Revised and accepted: December 29, 2010

» The authors report no commercial, proprietary or financial interest in the products or companies described in this article.

Contact address: Bruno Boaventura Vieira

Rua Capitão Pereira Lago, 994, apto 07, Ribeirão Preto/SP. CEP: 14.051-130

Email: brn_vieira@hotmail.com 


\section{INTRODUCTION}

The Class III malocclusions are characterized by more anterior positioning of the mandible in relation to the maxilla, considering that the discrepancy can be caused by the maxilla growth deficit, excessive mandibular prognathism or the combination of both. ${ }^{5,8,9,16,17}$ In general, the facial aspect is very compromised, motivating the patient to seek treatment. ${ }^{4,13,19}$ Regarding etiology, factors such as heredity and the environmental action are considered relevant. The treatment of the Class III malocclusion in adults is limited, requiring a multidisciplinary planning that provides functional and esthetic benefits for the maxillomandibular complex. The options may be a compensatory treatment or combined treatment, consisted of orthodontic-surgical treatment that may require advancement of the maxilla, retraction of the mandible or a combination of both. ${ }^{20}$ The main objectives of the orthognathic surgery are to obtain normal occlusion and improve the facial esthetic, resulting on the balance of the soft tissues of the face, besides the obtainment of functional improvement on mastication, phonation, breathing and occlusion, ${ }^{15,20}$ the reported case, also presents dental impaction, prolonged retention of deciduous tooth and presence of supernumerary tooth, that are common characteristics of orthodontic patients. ${ }^{2,10,12,14}$ For the success of dental traction, achieving an ideal positioning of the crown and root, previous procedures as the extraction of supernumerary teeth may be necessary. $1,6,11,24,25$

\section{CASE REPORT}

Female Caucasian patient, 14 years and 8 months old, presenting Angle Class III malocclusion, skeletal Class III pattern due to mandibular excessive growth, superior and inferior dental protrusion, overjet of $-3 \mathrm{~mm}$, overbite of $-1 \mathrm{~mm}$, congenital absence of tooth \#22, teeth \#13 and supernumerary impacted, tooth \#12 with conoid shape and partly erupted in supraversion, prolonged retention of tooth \#53, tendency to vertical growth of the face and facial asymmetry. Patient main complaint was the malposition of the teeth.

\section{FACIAL AND FUNCTIONAL ANALYSIS}

Analysis showed facial asymmetry, with concave profile, normal nasolabial angle, deficiency on the paranasal region, increased lower facial third, normal lip thickness with mentum prominence. On the functional analysis it was found: Nasal breathing, normal phonation, atypical
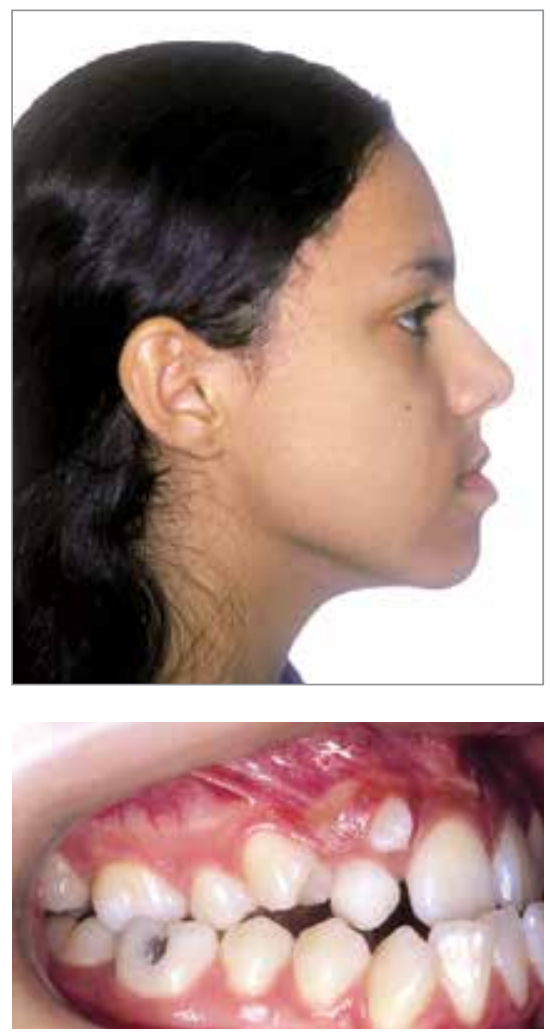
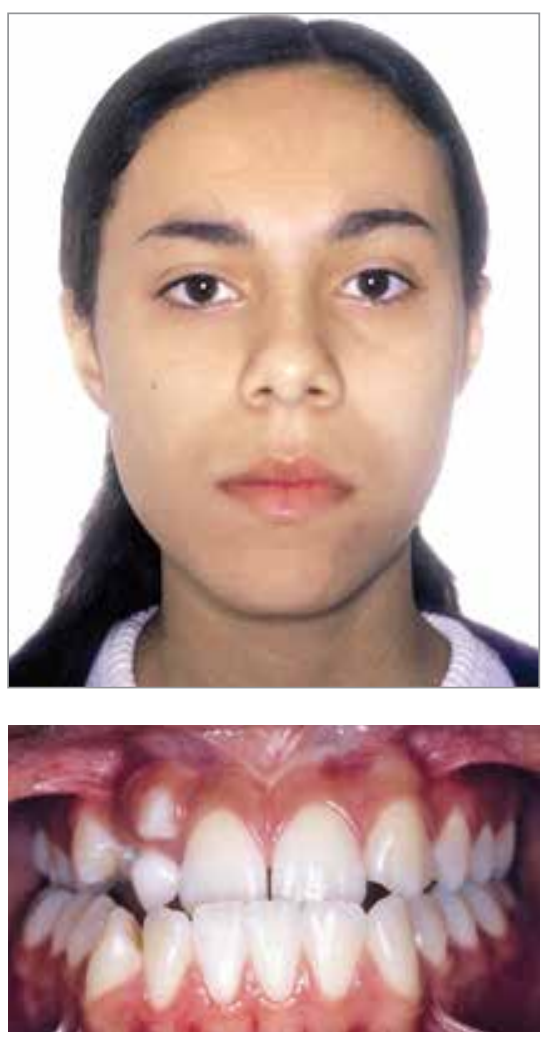

Figure 1 - Extraoral and intraoral initial photographs.

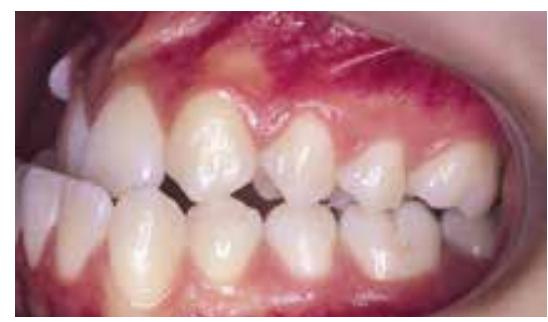



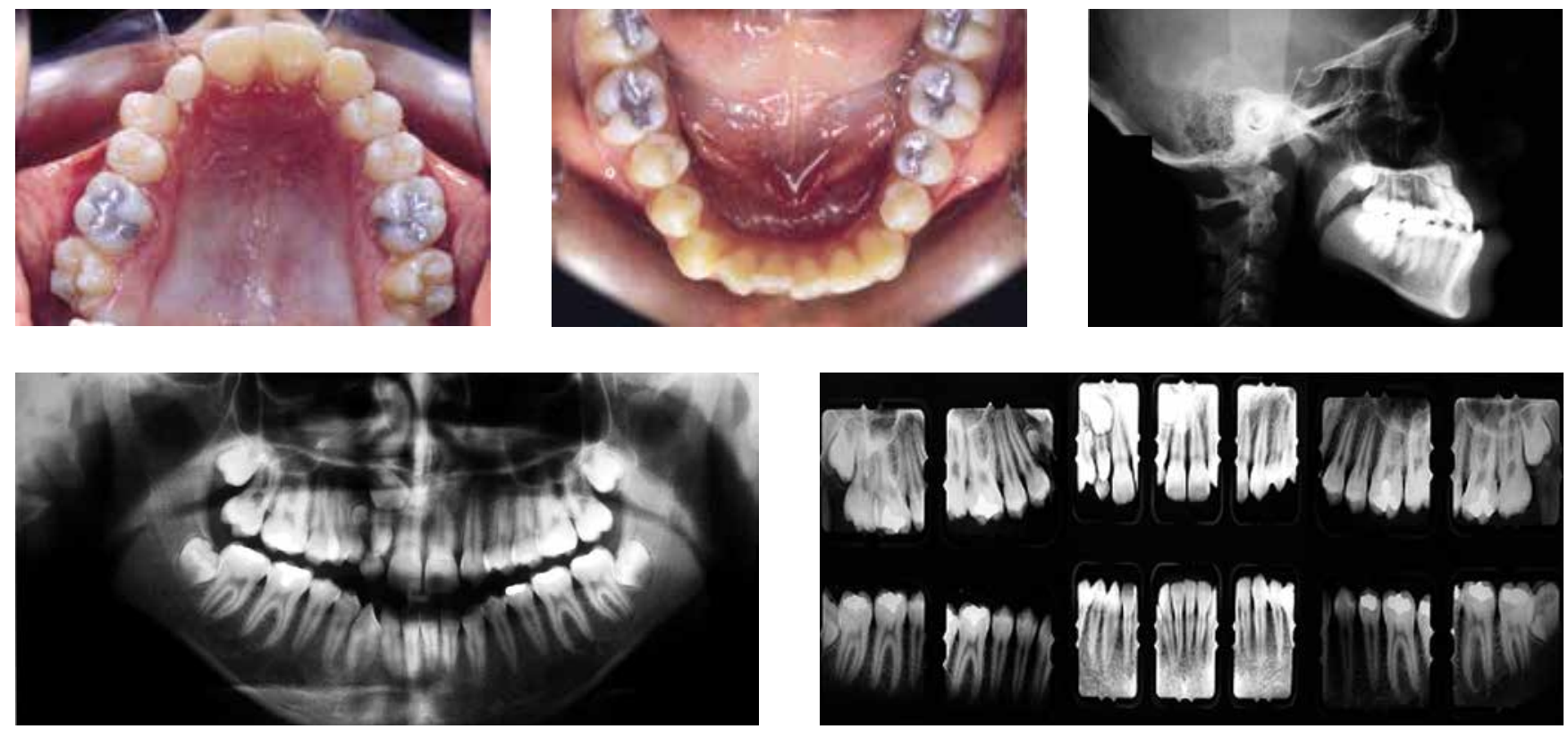

Figure 2 - Occlusal photographs and initial radiographs.
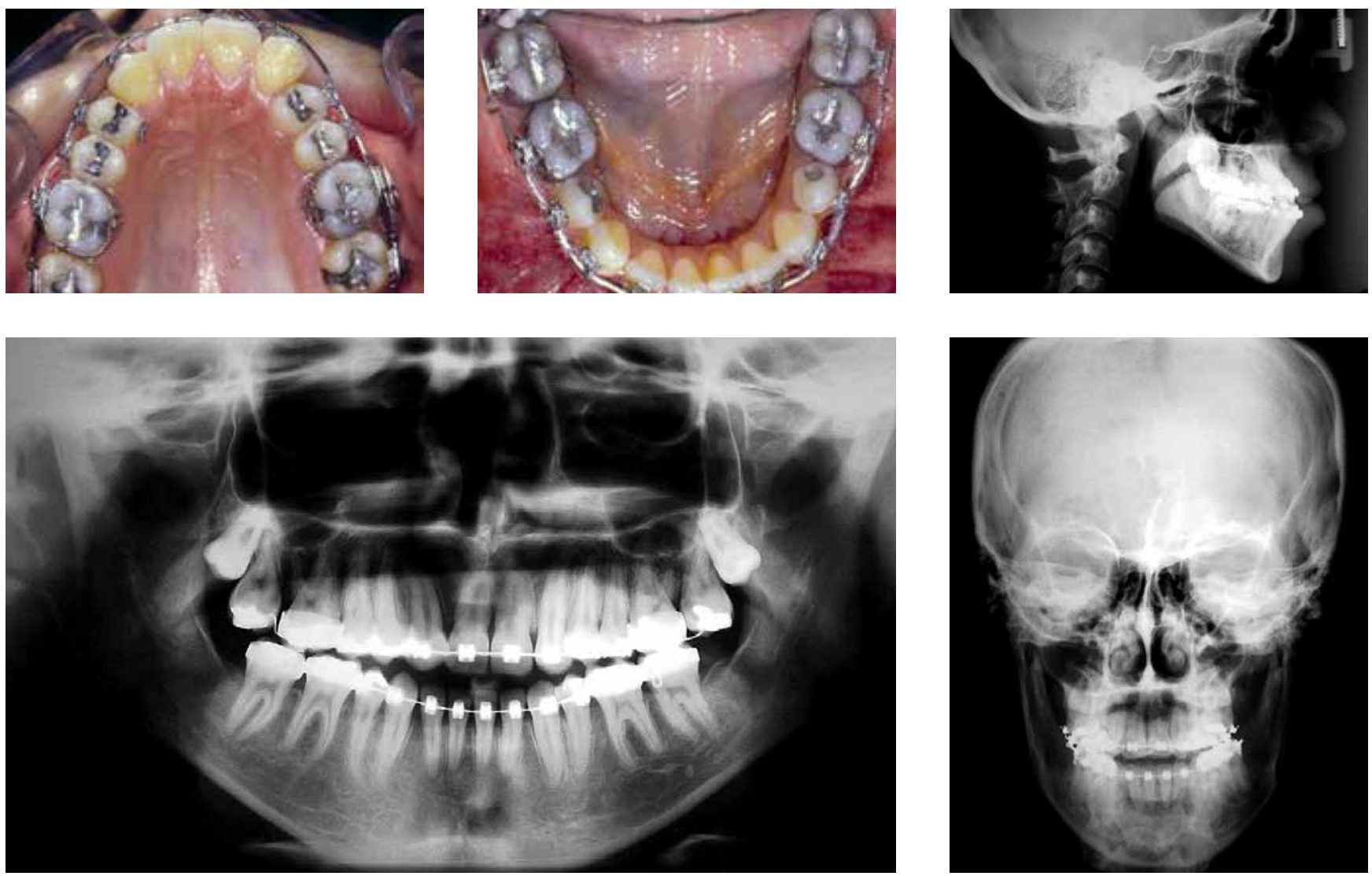

Figure 3 - Occlusal photographs and pre-surgical radiographs. 

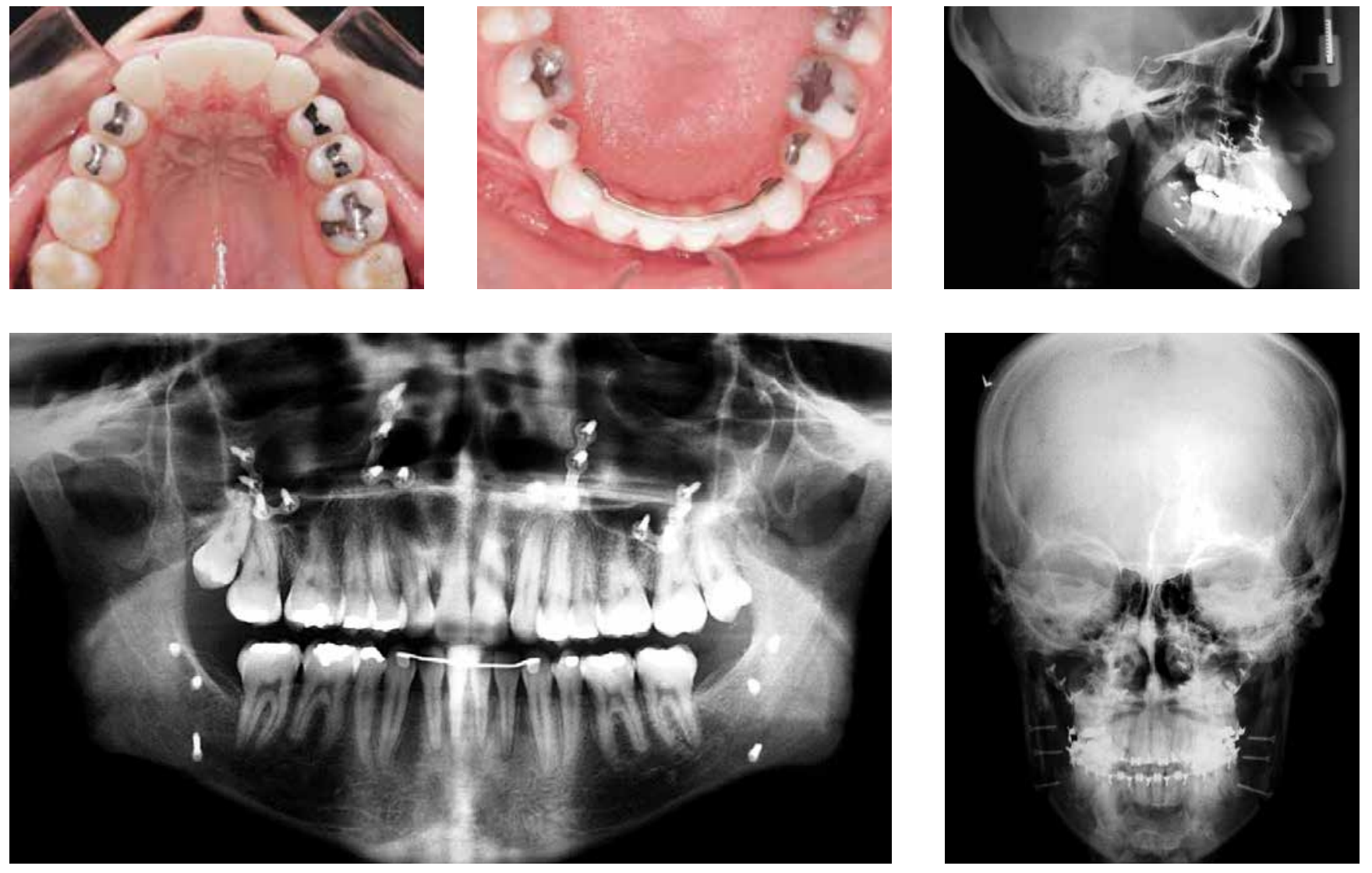

Figure 4 - Occlusal photographs and final radiographs.

swallowing, normal pharyngeal and palatine tonsils, with upper and lower lips in normal function, mandibular closing pattern with deviation to the right and ATM without any anomalies, however, presenting painful symptomatology during intense mastication.

\section{INTRAORAL CLINICAL EXAMINATION}

The patient presented good oral hygiene, periodontium with aspect of normality, absence of carious lesions, dental anomaly of number, shape and size, labial and lingual frenum with normal insertions and Class III relation of molars. According to Angle's classification, the patient presented a Class III malocclusion, with superior and inferior midline deviation to the right.

\section{INTERPRETATION OF CEPHALOMETRIC MEA- SURES AND ANALYSIS OF MODELS}

On the analysis of the skeletal pattern it was observed maxillary retrusion, mandibular protrusion, skeletal Class III malocclusion (ANB $=-2^{\circ}$ ), tendency to verti- cal growth of the face $\left(\mathrm{NSGn}=69^{\circ}, \mathrm{SN} \cdot \mathrm{GoGn}=37^{\circ}\right)$ with dolichofacial morphological pattern, according to Steiner's measures. ${ }^{23,24}$ The measures of the dental pattern showed protrusion and increase of axial inclinations of upper incisors $\left(1-\mathrm{NA}=6 \mathrm{~mm}\right.$ and $\left.1 . \mathrm{NA}=25^{\circ}\right)$ and protruded lower incisors with normal axial inclinations $\left(1-\mathrm{NB}=7 \mathrm{~mm}\right.$ and $\left.1 . \mathrm{NB}=25^{\circ}\right)$. The occlusal plane was inclined in relation to cranial base. On the model analysis, ${ }^{5,20}$ it was verified that the discrepancy on the upper arch was of $-2 \mathrm{~mm}$ and $-5.0 \mathrm{~mm}$ for the lower arch, upper arch contracted in relation to the lower and deep ogival palate. The upper midline, evaluated on study models, was $1.5 \mathrm{~mm}$ deviated to the right and the lower $3.5 \mathrm{~mm}$ to the right side, confirming the facial assessment.

\section{PRE-SURGICAL ORTHODONTIC TREATMENT}

The orthodontic treatment was initiated with the installation of the standard edgewise appliance (0.022 x 0.028-in), consisted of bracket bonding on 

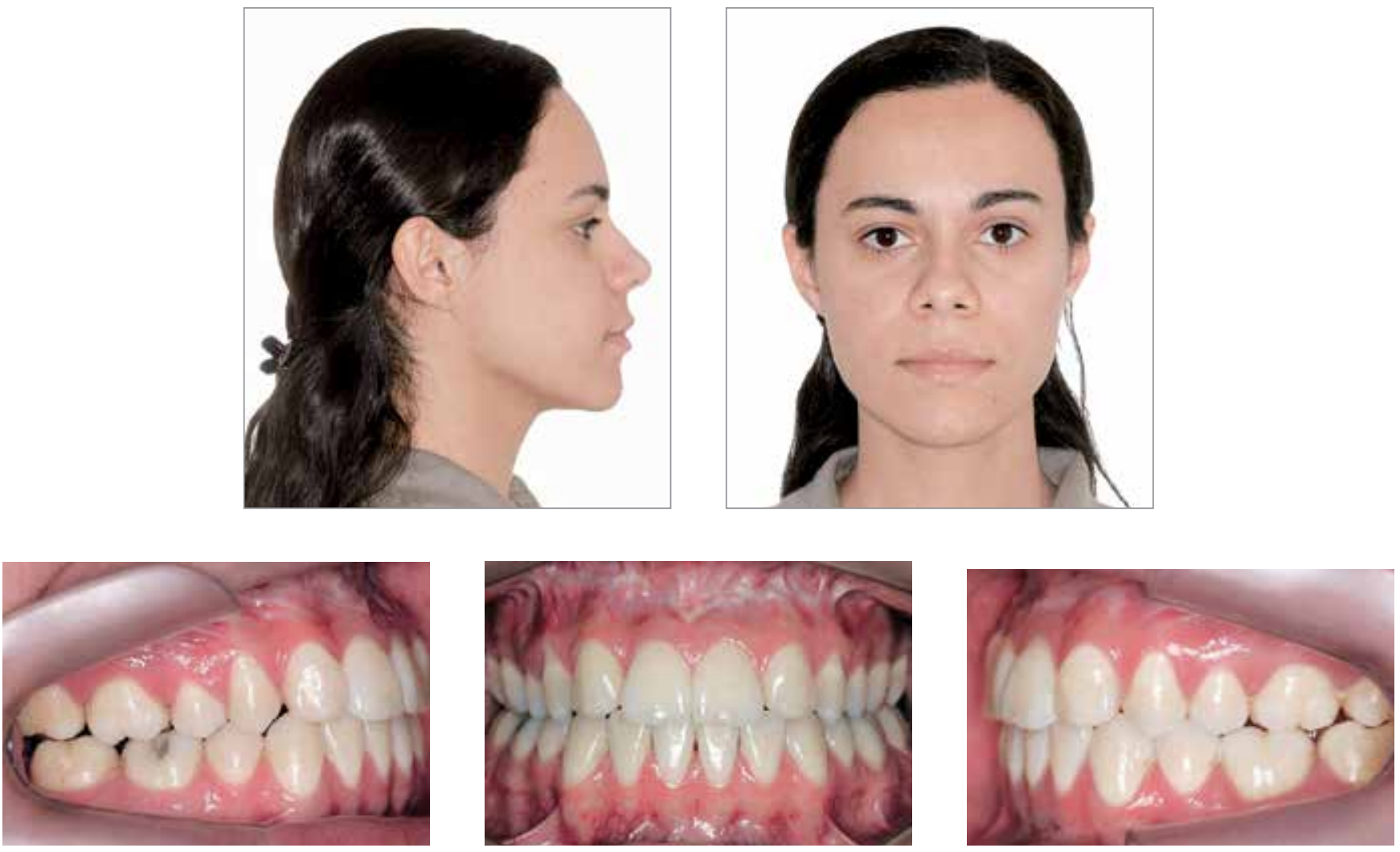

Figure 5 - Final extraoral and intraoral photographs.
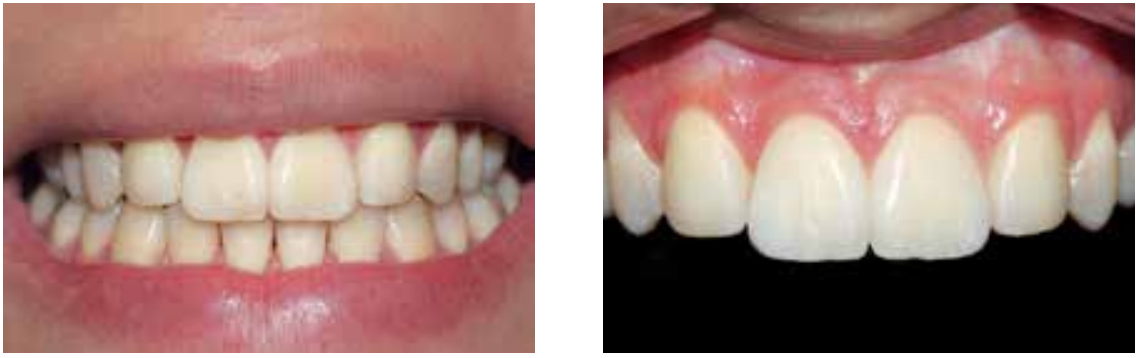

Figure 6 - Observe the canines esthetics.

upper and lower teeth, cemented rings on first molars of both arches and second lower molars.

It was initiated the alignment and levelling of the upper arch with stainless steel 0.014-in, 0.016-in, 0.018 -in and 0.020-in archwires.

It was performed extraction of the teeth \#53 (deciduous upper right canine), supernumerary and tooth \#12 (lateral upper right incisor). On the same surgical act, it was performed button bonding to the tooth \#13 in order to perform traction.

It was also indicated extraction of teeth \#38 and \#48, with a minimum of six months before the orthognathic surgery so that there was enough time for bone formation on the location where it would be performed the mandibular osteotomy.

The traction was done through a chain elastic and rubber type action line (GAC), connected to the tying wire installed during the act of dental extractions.

After traction, the right upper canine, was aligned and leveled through new stainless steel 0.014-in, 0.016 -in, 0.018-in and 0.020-in archwire.

For the lower arch, extraction of the second premolars was required. Alignment and levelling stainless steel 0.014-in, 0.016 -in, 0.018-in and 0.020-in archwires were made and installed, with anchorage type $\mathrm{C}$ planned on both sides. 
Table 1 - Table with initial and final values of the Steiner analysis

\begin{tabular}{|c|c|c|c|}
\hline \multirow{2}{*}{ Measures } & \multirow{2}{*}{$\begin{array}{l}\text { Normal } \\
\text { values }\end{array}$} & \multicolumn{2}{|c|}{ Age } \\
\hline & & 14 years & 22 years \\
\hline SNA & $82,0^{\circ}$ & $80,0^{\circ}$ & $84,0^{\circ}$ \\
\hline SNB & $80,0^{\circ}$ & $82,0^{\circ}$ & $82,0^{\circ}$ \\
\hline ANB & $2,0^{\circ}$ & $-2,0^{\circ}$ & $2,0^{\circ}$ \\
\hline SND & $78,0^{\circ}$ & $78,0^{\circ}$ & $77,0^{\circ}$ \\
\hline 1-NA & $4,0 \mathrm{~mm}$ & $6,0 \mathrm{~mm}$ & $6,0 \mathrm{~mm}$ \\
\hline 1.NA & $22,0^{\circ}$ & $25,0^{\circ}$ & $25,0^{\circ}$ \\
\hline $1-N B$ & $4,0 \mathrm{~mm}$ & $7,0 \mathrm{~mm}$ & $6,0 \mathrm{~mm}$ \\
\hline 1.NB & $25,0^{\circ}$ & $25,0^{\circ}$ & $25,0^{\circ}$ \\
\hline $\mathrm{Pg}-\mathrm{NB}$ & & $1,0 \mathrm{~mm}$ & $1,0 \mathrm{~mm}$ \\
\hline Pg-NB / (1-NB) & & $6,0 \mathrm{~mm}$ & $5,0 \mathrm{~mm}$ \\
\hline 1.1 & $131,0^{\circ}$ & $133,0^{\circ}$ & $127,0^{\circ}$ \\
\hline SN.PIO & $14,0^{\circ}$ & $21,0^{\circ}$ & $14,0^{\circ}$ \\
\hline SN.GoGn & $32,0^{\circ}$ & $37,0^{\circ}$ & $32,0^{\circ}$ \\
\hline NSGn & $67,0^{\circ}$ & $69,0^{\circ}$ & $69,0^{\circ}$ \\
\hline Line S-Ls 0 & $0 \mathrm{~mm}$ & $-1 \mathrm{~mm}$ & $0 \mathrm{~mm}$ \\
\hline Line S-Li 0 & $0 \mathrm{~mm}$ & $5 \mathrm{~mm}$ & $3 \mathrm{~mm}$ \\
\hline
\end{tabular}

On the lower arch 0.020-in, the partial distalization of the first molars and canines, was performed to obtain the alignment of the incisors. After finishing the alignment and leveling, the spaces were closed with loss of anchorage and mesialization of the first and second molars.

With the complete closure of the spaces ideal lower rectangular archwire $0.019 \times 0.025$-in, coordinated with the opposite and with necessary torques was set.

After alignment and levelling of both arches, closing of spaces from extractions, correct positioning of teeth on the bone base with ideal torques for each tooth, it was obtained study models to evaluate, on the pre-surgical phase, the correct intercuspation (Class I of molars and canines with coincident midlines).
Interdental hooks were welded on the upper and lower arch 0.019 x 0.025-in, for metallic individual tying wire. In this stage the patient was referred to combined orthognathic surgery of maxilla and mandible.

\section{POST-SURGICAL ORTHODONTIC TREATMENT}

The post-surgical orthodontic treatment consisted in finishing the intercuspation and the occlusal functions, through the adjustment of torque, characterization of upper canines in lateral incisors and use of intermaxillary elastics.

Functional adjustments of teeth \#14 and \#24 that substituted the upper canines were performed to obtain guides of disocclusion, Extractions of teeth \#18 and \#28 were also performed.

The upper and lower fixed appliances were removed and the retainers were installed, being in the upper arch a modified Hawley plate and, in the lower arch, lingual bar bonded to teeth \#33 and \#43 (Figs 5 and 6).

The patient was orientated to use upper retainer 24 hours a day, during a period of 12 months and after that the period of use should be overnight. The lower retainer should be kept for undetermined period. It was also recommended a speech treatment for adaptation to new muscle functions.

\section{FINAL CONSIDERATIONS}

The objectives of the treatment were achieved with the association of the orthodontic-surgical treatment. Molar Class I relation and normal overjet and overbite were obtained. It was performed the traction of tooth \#13, which, along with teeth \#23, replaced lateral upper incisors. The Class III malocclusion was well corrected, establishing a normal occlusal, facial and functional patterns. 


\section{REFERENCES}

1. Almeida R, Fuziy A, Almeida MR, Almeida Pedrin RR, Henriques JFC, Insabralde CMB. Abordagem da impactação e/ou irrupção ectópica dos caninos permanentes: considerações gerais, diagnóstico e terapêutica. Rev Dental Press Ortod Ortop Facial. 2001;6(1):93-116.

2. Becker A, Bimstein E, Shteyer A. Interdisciplinary treatment of multiple unerupted supernumerary teeth. Am J Orthod. 1982;81(5):417-22.

3. Bishara SE. Impacted maxillary canines: a review. Am J Orthod Dentofacial Orthop. 1992:101(2):159-71.

4. Bittencourt MAV. Má oclusão Classe III de Angle com discrepância anteroposterior acentuada. Rev Dental Press Ortod Ortop Facial. 2009;14(1):132-42.

5. Cao Y, Zhou Y, Li Z. Surgical-orthodontic treatment of Class III patients with long face problems: a retrospective study. J Oral Maxillofac Surg 2009;67(5):1032-8

6. Cappellette M, Cappellette Jr M, Fernandes LCM, Oliveira AP, Yamamoto LH, Shido FT, et al. Caninos permanentes retidos por palatino: diagnóstico e terapêutica: uma sugestão técnica de tratamento. Rev Dental Press Ortod Ortop Facial. 2008;13(1):60-73.

7. Capelozza Filho L, Martins A, Mazzotini R, da Silva Filho OG. Effects of dental decompensation on the surgical treatment of mandibular prognathism. Int J Adult Orthodon Orthognath Surg. 1996;11(2):165-80

8. Dale HC. Morphologic skeletal asymmetry, with a Class III skeletal discrepancy, treated without surgical intervention. World J Orthod. 2005:6(4):391-7.

9. Ellis E 3rd, McNamara JA Jr. Components of adult Class III malocclusion. J Oral Maxillofac Surg. 1984;42(5):295-305.

10. Fastlicht S. Treatment of impacted canines. Am J Orthod. 1954:40(12):891-905

11. Frank CA, Long M. Periodontal concerns associated with the orthodontic treatment of impacted teeth. Am J Orthod Dentofacial Orthop 2002;121(6):639-49.

12. Jacoby $\mathrm{H}$. The etiology of maxillary canine impactions. Am J Orthod. 1983;84(2):125-32

13. Kerr WJS, O'Donnell JM. Panel perception of facial attractiveness. Br J Orthod 1990:42(4):299-304.
14. Lewis PD. Preorthodontic surgery in the treatment of impacted canines. Am J Orthod. 1971;60(4):382-97.

15. Medeiros PJD, Quintão CCA, Menezes LM. Avaliação da estabilidade do perfil facial após tratamento orto-cirúrgico. Ortod Gaúch. 1999;3(1):5-23.

16. Miloro M. Combined maxillary and mandibular surgery. In: Fonseca RJ. Oral and maxillofacial surgery: orthognathic surgery. Philadelphia: Saunders; 2000. v. 2, p. 419-32

17. lino M, Ohtani N, Niitsu K, Horiuchi T, Nakamura Y, Fukuda M. Two-stage orthognathic treatment of severe Class III malocclusion: report of a case. $\mathrm{Br} J$ Oral Maxillofac Surg. 2004:42(2):170-2.

18. Mucha JN, Bolognese AM. Análise de modelos e ortodontia. Rev Bras Ortod. 1985;42(1-3):28-44.

19. Nicodemo D, Pereira MD, Ferreira LM. Effect of orthognatic surgery for class III correction on quality of life as measured by SF-36. Int J Oral Maxillofac Surg. 2008;37(2):131-4

20. Pangrazio-Kulbersh V, Berger JL, Janisse FN, Bayirli B. Long-term stability of Class III treatment; rapid palatal expansion and protraction facemask vs LeFort I maxillary advancement osteotomy. Am J Orthod Dentofacial Orthop. 2007:131(1):7.e9-19.

21. Steiner CC. Cephalometrics for you and me. Am J Orthod. 1953:39(10):729-55

22. Steiner CC. Cephalometrics in a clinical pratice. Angle Orthod. 1959:29(1):8-29.

23. Tavares HS, Gonçalves JR, Pinto AS, Rapoport A. Estudo cefalométrico das alterações no perfil facial em pacientes Classe III dolicocefálicos submetidos à cirurgia ortognática bimaxilar. Rev Dental Press Ortod Ortop Facial. 2005;10(5):108-21

24. Vilas Boas PC, Bernardes LAA, Pithon MM, Engel DP. Tracionamento ortodôntico de incisivos central e lateral superiores impactados: caso clínico. Rev Clin Ortod Dental Press. 2004;3(3):79-86

25. Wisth PJ, Norderval K, Bøoe OE. Comparison of two surgical methods in combined surgical orthodontic correction of impacted maxillary canines Acta Odontol Scand. 1976:34(1):53-7. 